\title{
Seroprevalence of Hepatitis C Virus Infection among Chronic Kidney Disease Patients on Maintenance Hemodialysis in a Tertiary Care Hospital
}

\author{
Nirmaladevi Somsundaram* and R. Vidhya Rani \\ Department of Microbiology, Government Mohan kumaramangalam Medial College, \\ Salem, Tamil Nadu, India \\ *Corresponding author
}

\begin{tabular}{|c|c|}
\hline & A B S T R A C T \\
\hline $\begin{array}{l}\text { Hepatitis C virus, } \\
\text { Chronic kidney } \\
\text { disease, } \\
\text { Hemodialysis, } \\
\text { ELISA, } \\
\text { Seroprevalance, } \\
\text { Blood transfusion. }\end{array}$ & \multirow{3}{*}{$\begin{array}{l}\mathrm{HCV} \text { is a major cause of increased morbidity and mortality in patients with chronic kidney } \\
\text { disease (CKD). Since, HCV is transmitted through blood and blood products prevalence of } \\
\text { anti-HCV among Hemodialysis (HD) patients is consistently higher among them. Factors } \\
\text { such as blood transfusion and frequent parenteral interventions have been shown to be } \\
\text { associated with increased risk of HCV infection. A total of } 107 \text { blood samples were } \\
\text { collected from CKD patients on maintenance hemodialysis in a tertiary care hospital and } \\
\text { the sera separated, stored at }-20^{\circ} \mathrm{C} \text { and tested for anti-HCV antibodies by using third } \\
\text { generation ELISA. Out of } 107 \mathrm{CKD} \text { Patients } 33(30.8 \%) \text { were positive for anti-HCV, of } 33 \\
\text { seropositives } 21(63.6 \%) \text { were males and } 12(36.4 \%) \text { were females. } 19 \text { (57.6\%) out of } 33 \\
\text { seropositives had received multiple blood transfusions and prevalence of HCV was higher } \\
\text { among ( } 75.7 \%) \text { those patients who had undergone increased duration and number of } \\
\text { hemodialysis. Hemodialysis patients should be routinely screened for HCV infection, } \\
\text { preferably using serological methods. Strict adherence to universal precautions along with } \\
\text { isolating HCV-infected dialysis patients might help to control disease spread in HD units. }\end{array}$} \\
\hline Article Info & \\
\hline $\begin{array}{l}\text { Accepted: } \\
\text { 17 June } 2017 \\
\text { Available Online: } \\
\text { 10 July } 2017\end{array}$ & \\
\hline
\end{tabular}

\section{Introduction}

Hepatitis $\mathrm{C}$ virus (HCV) infection is a major public health problem with an estimated global prevalence of $3 \%$. $\mathrm{HCV}$ is a major cause of increased morbidity and mortality in patients with chronic kidney disease (CKD) (Fabirizi F et al., 1997).

$\mathrm{HCV}$ is a single stranded positive sense RNA virus belonging to the family Flaviviridae and genus Hepacivirus. Prevalence of anti-HCV antibody among Hemodialysis (HD) patients is consistently higher than in general population indicating increased risk of acquiring $\mathrm{HCV}$ infection among them. HCV is a blood borne virus and the most common modes of infection are through transfusion of blood and blood products, unsafe infection practices and inadequate sterilization of medical equipments. A number of risk factors have been identified for $\mathrm{HCV}$ infection among dialysis patients, which includes prolonged vascular exposure, multiple blood transfusions, duration of end stage kidney disease, mode of dialysis, and the concurrent prevalence of HCV infection in the dialysis unit increase the risk of acquiring blood borne infections in these patients (Jasuja $\mathrm{S}$ et al., 2009).

Patients who are undergoing dialysis should be routinely screened for $\mathrm{HCV}$ infections preferably using serological methods. 
Development of diagnostic testing confirmed a high incidence and prevalence for $\mathrm{HCV}$ infections among HD patients. Currently, third-generation anti-HCV ELISA is largely in use and has shown greater sensitivity and specificity in patients on HD (Fabirizi et al., 1997).

Hepatitis C Virus infection remains frequent in patient receiving long term dialysis both in developed and developing countries like India (Fabrizi, 2012). The prevalence of anti-HCV in patients on hemodialysis from India is reported to be in the range of $3-45 \%$ (Agarwal, 1999).

There is wide variation in the prevalence of $\mathrm{HCV}$ infection among different dialysis units and countries as shown by Dialysis Outcomes and Practice Patterns Study (DOPPS) (Froio et al., 2003).

The prevalence of anti-HCV antibodies among dialysis patients was found to be $42 \%$ in France (Pragati Chigurupathi et al., 2015), $75 \%$ in Moldavia (Covic et al., 1999) and $49 \%$ in Syria (Othman et al., 2001).

Incidence and prevalence of $\mathrm{HCV}$ infection among patients on dialysis is declining in Western countries. In US, incidence has decreased from $1.7 \%$ in 1982 to $0.2 \%$ in 1997 (Tokars et al., 2000).

This decline is attributed to reduction in posttransfusion $\mathrm{HCV}$ infection with proper screening and implementation of universal precautions for infection control.

With this background and knowledge, this study was undertaken to determine the seroprevalence of $\mathrm{HCV}$ infection among chronic kidney disease patients undergoing maintenance hemodialysis in a tertiary care hospital.

\section{Materials and Methods}

A prospective study was conducted in a tertiary care hospital for a period of 3 months from June - August 2016 in those patients with chronic kidney disease undergoing maintenance hemodialysis were screened for anti- HCV. Renal transplant recipients were excluded from this study.

A total of 107 chronic kidney diseases were included in this study. Institutional ethical committee clearance and informed consent from the patients were obtained.

The socio demographic and clinical data such as age, sex, number of blood transfusions received and number of cycles of Hemodialysis undergone were collected in a pre-filled questionnaire format.

A total of 107 blood samples were collected and the sera separated, stored at $-20^{\circ} \mathrm{C}$ and tested for anti- HCV antibodies by using third generation ELISA.

\section{Results and Discussion}

Among the 107 CKD Patients 64 (59.8\%) were males and $43(40.2 \%)$ were females, of this $33(30.8 \%)$ were positive for anti- HCV. Among 33 (30.8\%) seropositive patients 21 $(63.6 \%)$ were males and $12(36.4 \%)$ were females. Thus the seroprevalance of $\mathrm{HCV}$ was significantly higher among males.

Out of 33 seropositive individuals 11 (33.3\%) were in the age group of 41-50 years, $8(24.2 \%)$ of them were in the age group of 51-60 years and $7(21 \%)$ patients were in $6^{\text {th }}$ decade of life. Out of 33 seropositives 4 $(12 \%)$ and $3(9 \%)$ patients were in the age group of $3^{\text {rd }}$ and $2^{\text {nd }}$ decade of life. So, in our study seroprevalance was high in patients with $4^{\text {th }}$ and $5^{\text {th }}$ decades of life. 
Since HCV is transmitted through blood and blood products, Blood transfusion is one of the important risk factor in $\mathrm{HCV}$ transmission. In our present study 19 (57.6\%) out of 33 seropositives had received more than 10 times of blood transfusion remaining $42.4 \%$ patients were received less than 10 transfusions. So, our study reveals that patients who had received multiple blood transfusion had high chances of $\mathrm{HCV}$ transmission

Based on number of cycles of hemodialysis the seroprevalence of $\mathrm{HCV}$ infection was categorized. $14(42.4 \%)$ and $11(33.3 \%)$ out of 33 seropositive patients have undergone 401500 and 301-400 cycles of hemodialysis respectively whereas the number of patients who have undergone less than 100 cycles of hemodialysis was only $3(6 \%)$ out of 33 seropositive patients were observed.

Thus, the highest prevalence of $\mathrm{HCV}$ infection $(75.7 \%)$ was in patients who have undergone more than 300 cycles of hemodialysis and the least prevalence was observed in patients who have undergone less than 100 cycles of hemodialysis. Hence, the risk of acquiring $\mathrm{HCV}$ infection increases as the duration and number of cycles of hemodialysis increases.

Patients with end-stage renal disease on maintenance hemodialysis are at high risk for $\mathrm{HCV}$ infection for which screening for anti$\mathrm{HCV}$ antibodies is highly recommended. Nosocomial transmission, prolonged vascular access, potential for exposure to infected patients and contaminated equipment and sharing of multi-dose heparin vials are some factors responsible for the high risk in HD patients

According to KDIGO guideline, the prevalence of $\mathrm{HCV}$ infection among dialysis patients in different parts of the world varies from $1 \%$ to $90 \%$. The lowest was reported in the European nation with less than 5\% prevalence (Fabrizio, 2013).

The prevalence of anti $\mathrm{HCV}$ in patients on haemodialysis from India is reported to be in the range of 3-45\% (Agarwal, 1999). 13.23\% by Reddy et al., at 2005, Salunkhe et al., in 1992 reported 45\%, Chadha et al., in 1993 reported 12.1\%, Sumathi et al., in 1993 reported 37.5\%, Agarwal et al., in 1999 reported 42\%, and Jaiswal et al., (2002) reported in a study from 1992-2000 reported prevalence of $30 \%$. Our study showed HCV the prevalence of $30.8 \%$ among the patients on Hemodialysis. It is concordant with similar studies in India carried out by $27.7 \%$ Jasuja et al., (2009) and $34.5 \%$ by Fabrizio (2013).

However, the above results in contrast with data from Europe and the United States, where anti-HCV has been detected in less than $5 \%$ among HD patients. This discrepancy could be due to the introduction of the screening program for blood donors and subsequent elimination of anti-HCV and other blood-borne viral diseases positive patients, proper sterilisation of medical equipments and thereby decreasing the prevalence of blood-borne viral diseases. (Nicolas S et al., 1994)

The prevalence rate of anti-HCV antibody was found to be higher among men than among women and in older patients, besides increased duration on dialysis, and it correlated with a history of blood transfusion, as reported in the literature (Medeiros MT et al., 2004).

In our study it has been observed that out of 33 seropositives 19 patients (57.6\%) had received more than 10 times of blood transfusion remaining $42.4 \%$ patients had received less than 10 times of transfusions. It shows that Blood transfusion is one of the 
sources of $\mathrm{HCV}$ transmission among HD patients. It is understood that all blood are screened before transfusion. Probably present method of blood screening could not detect some HCV positive blood sample. Hence, screening of HCV should be done by PCR and other Nucleic acid amplification test though these tests are expensive

Duration of dialysis has been reported to be significantly longer among anti-HCV positive patients compared to anti-HCV negative patients. In our study shows the prevalence of anti $\mathrm{HCV}$ was $6 \%$ in patients who had less than 100 cycles of HD in comparison to $75.7 \%$ in patients who had more than 300 cycles of HD indicating that the duration and number of cycles of HD is related to the risk of developing HCV infection.

In our study, only anti HCV was taken as criteria to diagnose $\mathrm{HCV}$ infection. Thus, although the limitation exists for the use of single anti HCV test, considering all factors, it is still a test of choice for HCV screening as recommended by Centers for Disease Control (CDC). It is necessary to develop a costeffective, reliable, and simple HCV screening test in this group of patients for early case detection and improving treatment outcome.

In order to prevent the nosocomial transmission of $\mathrm{HCV}$ among $\mathrm{HD}$ patients CDC has recommended special precautions such as strict adherence to 'universal precautions', careful attention to hygiene, and strict sterilization of dialysis machines (Sypsa et al., 2005).

\section{References}

Agarwal SK, Dash SC, Irshad M. Hepatitis C Virus infection during hemodialysis in India.JAssoc Physic Ind 1999; 47:113943.

Chadha MS, Arankalle VA, Jha J, Banerjee
K. Prevalence of Hepatitis B and C virus infection among hemodialysis in Pune (Western India). Vox Sang 1993; 64:127-8.

Covic A, Lancu L, Apetrei C, Scripcaru D, Volovat C, Mititiuc I, et al., Hepatitis virus infection in hemodialysis patients from Moldavia. Nephrol Dial Transplant 1999; 14:40-5.

F. Fabrizi; V. Dixit; P. Messa Impact of Hepatitis C on Survival in Dialysis Patients J Viral Hepat. 2012; 19(9):601607.

Fabirizi F, Lunghi G, Raffaele L, Guarnori I, Bacchini G, Corti M, et al., Serologic survey for control of hepatitis $\mathrm{C}$ in hemodialysis patients: Third-generation assays and analysis of costs. Nephrol Dial Transplant 1997; 12:298-303.

Fabrizio Fabrizi. Hepatitis C virus infection and dialysis: 2012 update. ISRN Nephrology. 2013; 2013: Article ID 159760, 11 pages. doi: $10.5402 / 2013 / 159760$

Froio N, Nicastri E, Commandini UV, Cherubini C, Felicioni F, Solmone M, et al., Contamination by hepatitis $\mathrm{B}$ and $\mathrm{C}$ viruses in dialysis setting. Am J Kidney Dis 2003; 42; 546-50.

Jaiswal SP, Chitnis DS, Salgia P, Sepaha A, Pandit CS. Prevalence of hepatitis viruses among chronic renal failure patients on hemodialysis in central India. Dialys Transplant 2002; 31:2348.

Jasuja S, Gupta A K, Choudhry R, Kher V, Aggarwal D K, Mishra A, Agarwal M, Sarin A, Mishra M K, Raina V. Prevalence and associations of hepatitis $\mathrm{C}$ viremia in hemodialysis patients at a tertiary care hospital. Indian J Nephrol 2009; 19:62-7

Medeiros MT, Lima JM, Lima JW, Campos Hde H, Medeiros MM, Coelho Filho JM. Prevalence and associated factors to hepatitis $\mathrm{C}$ in hemodialysis patients in 
Brazil. Rev Saude Publica 2004; Salunkhe PN, Naik SR, Semwal SN, Naik S, 38(2):187-93 Kher V. Prevalence of antibodies to Hepatitis C Virus in HBs Ag negative hemodialysis patients. Indian $J$ Gastroenterol1992; 11:164-5.

Trepo, Stephan D. Twelve years natural history of hepatitis $\mathrm{C}$ virus infection in haemodialysis patients in France. Kidney Int 1994; 46(2):50411

Othman B, Monem F. Prevalence of antibodies to hepatitis $\mathrm{C}$ virus among hemodialysis patients in Damascus, Syria. Infection 2001; 29:262.

Pragati Chigurupathi, Subbarayudu, SarathBabuStudy of incidence of hepatitis $\mathrm{C}$ virus infection in hemodialysis patients. Date of publication: 16 jan 2015.

Reddy A K, Murthy KD, Lakshmi V. Prevalence of HCV Infection in Patients on Haemodialysis: Survey by Antibody and Core Antigen Detection. Indian $\mathbf{J}$ Med Microbiol 2005; 23:106-10

Sumathi S, Valliammai T, Thyagarajan SP, Malathy S, Madanagopalan N, Sankarnarayan V, et al., Prevalence of hepatitis $\mathrm{C}$ virus infection in liver disease, renal disease and voluntary blood donors in south India. Indian $J$ Med Microbio 1 1993; 11:291-7.

Sypsa V, Psichogiou M, Katsoulidou A, et al., Incidence and patterns of hepatitis $\mathrm{C}$ virus seroconversion in a cohort of hemodialysis patients. Am J Kidney Dis 2005; 45(2):334-43

Tokars J, Miller ER, Alter MJ, Arduino MJ. National surveillance of dialysis associated diseases in the United States, 1997. Semin Dial 2000; 13:75-85.

\section{How to cite this article:}

Nirmaladevi Somsundaram and Vidhya Rani, R. 2017. Seroprevalence of Hepatitis C Virus Infection among Chronic Kidney Disease Patients on Maintenance Hemodialysis in a Tertiary Care Hospital. Int.J.Curr.Microbiol.App.Sci. 6(7): 1416-1420.

doi: https://doi.org/10.20546/ijcmas.2017.607.169 